\title{
Determination of Minimum Inhibitory Concentration (MIC) of Imipenem against Salmonella typhi
}

\author{
Sanjoy Saha ${ }^{1 *}$, RR Gomes², Khan Shakil Ahmed ${ }^{3}$, Serajul Islam ${ }^{4}$, Shyamal Kumar Saha ${ }^{5}$, MM Islam ${ }^{6}$, Kishore \\ Kumar Biswas ${ }^{7}$, Shib Prasad Saha ${ }^{8}$
}

Abstract:
Objective: To determine the MIC of Imipenem against Salmonella Typhi.

Study Design: An interventional study.

Place of Study: Department of Pharmacology \& Therapeutics in collaboration with Department of Microbiology at Ad-din Sakina Women's Medical College, Jashore.

Study Duration: January 2018 to May 2018.

Methodology: MIC of Imipenem was determined by Broth Dilution Technique against standard strain of Salmonella typhi ATCC 24683.

Result: The MIC of Imipenem against Salmonella typhi was $0.75 \mu \mathrm{g} / \mathrm{ml}$.

Conclusion: Imipenem is a potential therapeutic agent for Salmonella typhi infection.

\section{Introduction:}

Infections with Salmonellae can result in various clinical presentations like enteric fever, gastroenteritis, septicemia with or without supportive lesion and carrier state. Typhoid fever is endemic in developing countries, more so in Indian subcontinent. ${ }^{1}$ Salmonella infections, especially those involving blood stream, have high mortality rate (about 30\%). This can be reduced to about $1 \%$ with appropriate use of antibiotics. $^{2,3}$ Salmonella typhi and paratyphi A, B and C cause typhoid fever, while non typhoidal Salmonellae (NTS) that has more than 2500 serotypes, cause gastroenteritis and

1. Associate Professor and Head, Department of Pharmacology \& Therapeutics, Ad-din Sakina Women's Medical College, Jashore \& PhD fellow, Bangladesh University of Professionals, Dhaka.

2. Associate Professor, Department of Medicine, Ad-din Women's Medical College, Dhaka.

3. Professor \& Head, Department of Forensic Medicine, Ad-din Akij Medical College, Khulna.

4. Associate Professor \& Head, Department of Community Medicine, Ad-din Sakina Women's Medical College, Jashore.

5. Professor \& Head, Department of Pharmacology \& Therapeutics, Mymensingh Medical College, Mymensingh.

6. Assistant Professor, Department of Pharmacology \& Therapeutics, Ad-din Sakina Women's Medical College, Jashore.

7. Assistant Professor, Department of Paediatrics, Ad-din Sakina Women's Medical College, Jashore

8. Assistant Professor \& Head, Department of Anesthesiology, Ad-din Sakina Women's Medical College, Jashore.

*Corresponding Author:

Dr. Sanjoy Saha

Associate Professor \& Head,

Department of Pharmacology \& Therapeutics

Ad-din Sakina Women's Medical College, Jashore

Email: dr.sanjoysahammc@gmail.com invasive infections like meningitis and osteomyelitis in immune compromised patients and children. ${ }^{4}$ Salmonella typhi is mostly acquired directly or indirectly through human feces by fecal-oral route from the diseased person or a carrier. Threat of growing resistance to antibiotics is of grave concern to human health. Resistant strains also lead to prolonged illness and more rate of complications. ${ }^{5}$ Resistance of Salmonella Typhi to chloramphenicol, cotrimoxazole and ampicillin developed in the 1980s. This led to an increasing use of fluoroquinolones. Gradually resistance also developed to fluoroquinolones. High prevalence of antibiotic resistant Salmonellae leads to treatment failure. Multi-drug resistant (MDR) strains (resistant to chloramphenicol, ampicillin and cotrimoxazole) are very common. Resistance to third generation cephalosporins is beginning to emerge. Due to development of resistance, therapeutic options for treatment of typhoid and other Salmonella infections are getting limited. Outbreaks of MDR Salmonella (S.) Typhi may be difficult to manage, especially in developing countries where resources are already limited. Outbreaks have been reported throughout the world especially in south-east Asia, Indian subcontinent, Africa and South America. ${ }^{6,7}$ An outbreak of MDR S. Typhi in late 1990s in Tajikistan caused more than 24,000 infections. ${ }^{8}$ Hence, there is dire need to explore new avenues for treatment of resistant Salmonellae. The aim of this study was to determine MIC of Imipenem against Salmonella typhi which is not commonly used for treatment of Salmonella infections.

\section{Materials and method:}

The interventional study was performed in the department of pharmacology and therapeutics in collaboration with the department of Microbiology at Ad-din Sakina Women's Medical College, Jashore during the period of January 2018 to May 2018. 
Collection of antibiotic Imipenem: A Betalactum antibiotic (Injectable form), $500 \mathrm{mg}$ vial was bought from local market, manufactured by Renata Pharmaceuticals LTD, Bangladesh.

Test organism: Standard reference strain of Salmonella typhi, ATCC 24683 was collected from Department of Microbiology, Ad-din Sakina Women's Medical College, Jashore.

Procedure of Experiment: Determination of MIC of Imipenem against test organisms

Technique: Broth dilution.

Preparation of stock solution of Imipenem: Five hundred (500) $\mathrm{mg}$ of Imipenem powder was mixed well with $500 \mathrm{ml}$ of sterile Distilled Water (DW) by sterile syringe. The prepared Imipenem injection had the concentration of $500 \mathrm{mg}$ in 500 $\mathrm{ml}$. So, $1 \mathrm{ml}$ solution contain $1 \mathrm{mg}$ Imipenem (Stock Imipenem solution-I). Then $1 \mathrm{ml}$ of stock Imipenem solution-I was mixed with $99 \mathrm{ml}$ of sterile D/W. This 1:100 dilution of stock Imipenem solution-I had the concentration of $10 \mu \mathrm{g} / \mathrm{ml}$. This solution was marked as Stock Imipenem Solution-II which was used as stock solution for the determination of MIC of Imipenem.

\section{Calculations:}

Imipenem $500 \mathrm{mg}+500 \mathrm{ml} \mathrm{D} / \mathrm{W}$.

So, $500 \mathrm{mg}$ Imipenem in $500 \mathrm{ml}$

Thus $1 \mathrm{ml}$ contains $1 \mathrm{mg}$ of Imipenem (Stock Imipenem Solution-I)

$1 \mathrm{ml}$ of solution $+99 \mathrm{ml} \mathrm{D} / \mathrm{W}(1: 100$ dilution $)$.

So, $100 \mathrm{ml}$ contains $1 \mathrm{mg}$ Imipenem $=1000 \mu \mathrm{g}$ Imipenem

So, in $1 \mathrm{ml}$, the concentration is $1000 / 100=10 \mu \mathrm{g}$ Imipenem $/ \mathrm{ml}$ (Stock Imipenem Solution-II)

This stock Imipenem solution-II (concentration $10 \mu \mathrm{g} / \mathrm{ml}$ ) was used for the determination MIC of Imipenem by broth dilution technique.
Preparation of different concentrations of Imipenem solution:

Set - I: Imipenem solution was made by adding $0.25 \mathrm{ml}$ of stock Imipenem solution-II with $9.75 \mathrm{ml}$ of Trypticase soya broth medium. The concentration of Imipenem in this dilution was $0.25 \mu \mathrm{g} / \mathrm{ml}$.

\section{Calculation:}

$1 \mathrm{ml}$ of stock Imipenem solution contains $10 \mu \mathrm{g}$ of Imipenem. (Stock Imipenem Solution-II)

So, $.25 \mathrm{ml}$ Imipenem solution contains $2.5 \mu \mathrm{g}$ of Imipenem

So $10 \mathrm{ml}$ of set I preparation contains $2.5 \mu \mathrm{g}$ of Imipenem

And thus $1 \mathrm{ml}$ of set I preparation contains $25 \mu \mathrm{g}$ of Imipenem

Set - II: Imipenem solution was made by adding $0.5 \mathrm{ml}$ of stock Imipenem solution-II with $9.5 \mathrm{ml}$ of Trypticase soya broth medium. The concentration of Imipenem in this dilution was $0.5 \mu \mathrm{g} / \mathrm{ml}$.

Similarly, Set-III, IV, V and VI of Imipenem solution respectively were made by adding measured amount of stock Imipenem solution-II with measured amount of broth medium. The concentrations of Imipenem were $0.75 \mu \mathrm{g} / \mathrm{ml}, 1$ $\mu \mathrm{g} / \mathrm{ml}, 1.5 \mu \mathrm{g} / \mathrm{ml}$ and $2 \mu \mathrm{g} / \mathrm{ml}$ respectively: (Table 1 ).

Control - 1: was made with $10 \mathrm{~m} 1$ of Trypticase soya broth medium (to be inoculated with bacterial suspension) in test tubes.

Control -2: was made with $10 \mathrm{~m} 1$ of Trypticase soya broth medium (no inoculation with bacterial suspension) in test tubes. (Table 1)

With each $10 \mathrm{ml}$ preparation except control-1 (set VII) $20 \mu \mathrm{l}$ bacterial suspensions were added after matching its opacity with that of $0.5 \mathrm{McF}$ arland Standard.

TABLE 1: Composition and different concentrations of working Imipenem solutions and the controls:

\begin{tabular}{|c|c|c|c|c|c|}
\hline No. of Sets & $\begin{array}{l}\text { Stock Imipenem } \\
\text { solution-II (ml) }\end{array}$ & $\begin{array}{l}\text { Trypticase soya } \\
\text { Broth media (ml) }\end{array}$ & Total (ml) & $\begin{array}{l}\text { Concentration of } \\
\text { Imipenem }(\mu \mathrm{g} / \mathrm{ml})\end{array}$ & $\begin{array}{l}\text { Test } \\
\text { organism }(\mu \mathrm{l})\end{array}$ \\
\hline I & 0.25 & 9.75 & 10 & 0.25 & 20 \\
\hline II & 0.5 & 9.50 & 10 & 0.5 & 20 \\
\hline III & 0.75 & 9.25 & 10 & 0.75 & 20 \\
\hline IV & 1 & 9 & 10 & 1 & 20 \\
\hline V & 1.5 & 8.5 & 10 & 1.5 & 20 \\
\hline VI & 2 & 8 & 2 & 2 & 20 \\
\hline VII & Control-1 & 10 & 10 & - & - \\
\hline VIII & Control-2 & 10 & 10 & - & 20 \\
\hline
\end{tabular}



Inoculation of bacterial suspension to different
concentrations of stock Imipenem in test tubes:

After matching the turbidity of bacterial suspension with 0.5 McFarland standard, $20 \mu 1$ or one drop $(0.02 \mathrm{ml})$ of bacterial suspension of Salmonella typhi is inoculated. These inoculums were also added to the control -2 except Control-1.

Incubation: The test tubes were marked set wise with black marker and were placed in the incubator at $37^{\circ} \mathrm{C}$ for $18-24$ hours.

\section{Examinations of test organisms in different dilutions and concentrations of Imipenem:}

After 18 to 24 hours of incubation at $37^{\circ} \mathrm{C}$, the growth of test organisms in each preparation of Imipenem was examined and compared against that of control by matching their turbidity. The clear preparations were considered as no growth of bacteria and turbid one as growth of bacteria. The MIC was reported as lowest concentration of Imipenem required to prevent the visible growth of test organisms. The observations and results of the experiment were shown in table- 2 .
Subculture of materials from effective dilutions of Imipenem in MacConkey agar media:

The materials from last two sets of growth and all sets of no growth of Imipenem preparations were sub cultured in the pure MacConkey (solid) media plates (without antibiotic and antibiotic mixed media). After 18 to 24 hours of incubation at $37^{\circ} \mathrm{C}$, the growth of test organisms were examined.

\section{Observations and results:}

Table-2 shows visible growth of Salmonella typhi observed at Set-I to Set-II. But the organisms failed to grow at Set-III to Set-VI. So the minimum inhibitory concentration (MIC) of Imipenem against Salmonella typhi was in $0.75 \mu \mathrm{g} / \mathrm{ml}$. Table- 2 also showed control-1 containing Trypticase soya broth medium without any bacterial inoculam had no visible growth and control -2 containing Trypticase soya broth medium with bacterial inoculam observed their visible growth.

Result of Experiment: The MIC of Imipenem against Salmonella typhi was $0.75 \mu \mathrm{g} / \mathrm{ml}$ at set III.

Table 2: MIC of Imipenem against Salmonella typhi

\begin{tabular}{llc}
\hline No of Sets & Concentration $(\mu \mathrm{g} / \mathrm{ml})$ & Salmonella typhi \\
\hline Set-I & 0.25 & Growth \\
Set-II & 0.5 & Growth \\
Set-III & $0.75($ MIC of S. typhi) & No Growth \\
Set-IV & 1 & No Growth \\
Set-V & 1.5 & No Growth \\
Set-VI & 2 & No Growth \\
Set-VII & Control-1 (Trypticase soya broth + No bacteria inoculation) & No Growth \\
Set-VIII & Control-2 (Trypticase soya broth+ Bacterial inoculation with no antibiotic) & Growth \\
\hline
\end{tabular}

\section{Discussion:}

The study was conducted during the period of January 2018 to May 2018 in the department of Pharmacology and Therapeutics with the collaboration of Department of Microbiology, Ad-din Sakina Women's Medical College, Jashore to determine the MIC of antibiotic Imipenem against standard strain of Salmonella typhi. It was an interventional study. The MIC of antibiotic Imipenem was determined by broth dilution technique. The stock solution of Imipenem was made. Then the working solution of various concentrations was made by dilution the stock Imipenem solution. The concentrations were $0.25 \mu \mathrm{g} / \mathrm{ml}, .5 \mu \mathrm{g} / \mathrm{ml}$, and $0.75 \mu \mathrm{g} / \mathrm{ml}, 1$ $\mu \mathrm{g} / \mathrm{ml}, 1.5 \mu \mathrm{g} / \mathrm{ml}$, and $2 \mu \mathrm{g} / \mathrm{ml}$. The MIC of Imipenem against Salmonella typhi was $0.75 \mu \mathrm{g} / \mathrm{ml}$. A near similar type of study was done at Department of Pathology and Microbiology, Aga Khan University Hospital, Karachi, Pakistan where the investigators found the MIC of Imipenen against Salmonella typhi was $0.5 \mu \mathrm{g} / \mathrm{ml}^{9}$ which is nearer to our study. Another study was done at Nepal where the MIC of Imipenem was determined against MDR Salmonella spp where the MICs varies $2-8 \mu \mathrm{g} / \mathrm{ml}$ in respect of species. ${ }^{10}$

\section{Conclusion:}

From the study it is evident that the MIC of Imipenem is much lower than other Salmonella sensitive antibiotics like Ciprofloxacin and Azythromycin. But indiscriminate use of this antibiotic will cause antibiotic resistance. As Imipenem is a potential therapeutic agent, its use should be restricted on the basis of blood culture and in MDR cases of typhoid fever only.

\section{References:}

1. Ochiai RL, Acosta CJ, Danovaro-Holliday MC, Baiqing D, Bhattacharya SK, Agtini MD et al. A study of typhoid fever in five Asian countries: disease burden and implications for controls. Bull World Health Organ 2008; 86(4):260-8.

2. Mirza SH, Beeching NJ, Hart CA. The prevalence and clinical features of multi-drug resistant Salmonella Typhi infections in Baluchistan, Pakistan. Ann Trop Med Parasitol 1995; 89(5): 515-9.

3. Mermin JH, Townes JM, Gerber M, Dolan N, Mintz ED, Tauxe RV. Typhoid fever in the United States, 1985-1994: changing risks of international travel and increasing antimicrobial resistance. Arch Intern Med 1998; 158(6):633-8. 
4. Gordon MA, Kankwatira AM, Mwafulirwa G, Walsh AL, Hopkins MJ, Parry CM et al. Invasive non-typhoid Salmonellae establish systemic intracellular infection in HIV-infected adults: an emerging disease pathogenesis. Clin Infect Dis 2010; 50(7):953-62.

5. Koul PB, Murali MV, Sharma PP, Ghai OP, Ramchandran VG, Talwar V. Multi-drug resistant Salmonella Typhi infection: clinical profile and therapy. Indian Pediatr 1991; 28(4):357-61.

6. Mirza SH, Beeching NJ, Hart CA. Multi-drug resistant typhoid: a global problem. $J$ Med Microbiol 1996; 44(5):317-9.

7. Parry CM, Hien TT, Dougan G, White NJ, Farrar JJ. Typhoid fever. N Engl J Med 2002; 347(22):1770-82.

8. Tarr PE, Kuppens L, Jones TC, Ivanoff B, Aparin PG, Heymann DL. Considerations regarding mass vaccination against typhoid fever as an adjunct to sanitation and public health measures: potential use in an epidemic in Tajikistan. Am J Trop Med Hyg 1999; 61(1):163-70.
9. Saba Qaiser, Seema Irfan, Erum Khan, Tanwir Ahsan, Afia Zafar. In Vitro Susceptibility of typhoidal Salmonellae against newer antimicrobial agents: A search for alternate treatment options: Journal of Pakistan Medical Association. August 2017, 67 (8): $1128-29$

10. Bharat M.Pokharel, JanakKoirala, Rajan K.Dahal, Shyam K.Mishra, Prem K.Khadga \& N.R.Tuladhar. Multidrug-resistant and extended-spectrum beta-lactamase (ESBL)-producing Salmonella enterica (serotypes Typhi and Paratyphi A) from blood isolates in Nepal: surveillance of resistance and a search for newer alternatives: International Journal of Infectious Diseases. November 2006, 10 (6):434-438. 